\section{A Time for Boldness? Exploring the Space for Senate Reform}

\author{
Michael Burton \& Steve Patten*
}

\section{Introduction}

It was thirty years ago this past March that Alberta's Select Special Committee on Upper House Reform released its influential 1985 report that helped to reframe discussions on Senate reform and popularize proposals for a "Triple-E" Senate. ${ }^{1}$ The Committee's report built on the work of a Canada West Foundation task force that argued effective regional representation in Parliament requires a Senate that is equal (in terms of provincial representation), elected, and effective (in terms of its legislative powers). ${ }^{2}$ The Alberta Committee's Report popularized these ideas and helped to frame the Senate reform debate in terms of commitments to electoral democracy and rebalancing federalism, especially in terms of the representation of territorial interests at the federal level.

The subsequent emergence of the Reform Party of Canada, with its commitment to bringing in the west through a combination of parliamentary and democratic reform, including the establishment of a Triple-E Senate, helped to ensure that Senate reform would feature prominently in the post-Meech constitutional negotiations that produced the Charlottetown Accord. But the failure of the Charlottetown Accord with its watered-down Triple-E Senate reform provisions - and the subsequent 1995 Quebec referendum shut down any immediate hope of constitutional or Senate reform. Despite con- tinued enthusiasm within the Reform Party and Alberta political circles, it was clear Senate reform would not be a federal priority under the Liberal governments of Jean Chrétien.

Following the 2006 election, Stephen Harper's Conservative minority government introduced Bills S-4 and C-43, which proposed term limits and consultative Senate elections, initiatives Prime Minister Harper described as "a step in fulfilling our commitment to make the Senate more effective and more democratic."3 Although opposition objections ensured these Bills would not pass in a minority government context, the Harper government reintroduced multiple versions of both these bills during the $39^{\text {th }}$ and $40^{\text {th }}$ minority parliaments. Then, following their 2011 majority victory, the Conservatives brought their proposals for consultative elections and term limits together in a single piece of legislation Bill C-7, the Senate Reform Act ${ }^{4}$ - that Stephen Harper described as the first step in a process that would eventually culminate in constitutional amendment and an elected Senate. ${ }^{5}$ This reignited the hopes of long-term adherents to the Triple-E Senate, including one-time members of the Reform Party who now make up a significant faction within the Conservative Party's leadership and base.

Not unexpectedly, however, the government of Quebec objected to Harper's unilateral initiative and, in May 2012, Premier Jean Charest's 
government referred the issue of the constitutionality of the Senate Reform Act to the Quebec Court of Appeal. The federal government's response was to preempt the Quebec reference by initiating its own reference to the Supreme Court of Canada, a lengthy six-question reference that asked the Court to rule on which constitutional amending procedures would apply to a variety of reform initiatives - ranging from term limits to consultative elections, removal of property qualifications, and abolition. ${ }^{6}$ On April 25, 2014, the Supreme Court advised that it would be unconstitutional for the federal government to proceed unilaterally with Bill C-7 as reforms dealing with the selection or length of Senatorial terms would be subject to constitutional amending provisions requiring the support of the federal government and at least seven provinces representing at least half of the Canadian population (known as the general amending formula, or the 7/50 rule). Of the matters pertaining to Senate reform considered by the Court, only the property and net worth qualifications can be amended unilaterally by the federal government. Moreover, abolition of the Senate would require unanimous federalprovincial agreement. ${ }^{7}$

Given the challenges associated with achieving such levels of federal-provincial agreement, the Harper Conservatives and many others within Canada's political class were of the opinion that Senate reform was now "impossible." But, others appreciated the procedural clarity provided by the Reference re Senate Reform and hoped for a renewed national dialogue on reforming the Upper House of the Canadian Parliament. It was in this spirit that the University of Alberta's Centre for Constitutional Studies organized a conference marking the $30^{\text {th }}$ anniversary of the report of Alberta's Select Special Committee. The conference - held March 13-14, 2015 - brought together academics, legal practitioners, Senators, and interested members of the public for discussions framed by the slogan "Time for Boldness on Senate Reform." Presenters surveyed the postreference legal and political terrain, explored the space for Senate reform, and debated competing visions for reform. Readers with an interest in the conference can view the conference panels and speakers on the Centre's YouTube channel. ${ }^{8}$
This article reviews and builds on highlights of the presentations at the conference in the hopes of identifying an emerging agenda for rethinking the democratization of the Senate, and concludes by asking if the ideas and proposals generated by the conference are truly bold enough.

\section{The Altered Political and Constitutional Space for Senate Reform}

Interestingly, while Kate Glover, a doctoral candidate in the Faculty of Law at McGill University and junior counsel for the Amicus Curiae in the Reference re Senate Reform, provided an insightful analysis of the implications of what the Supreme Court said about the applicability of various amending formula contained in Part V of the Constitution Act, 1982, several of the speakers at the conference veered away from focusing on this aspect of the court's ruling. They concentrated, instead, on what the Court said about the framers' original intent with regard to the role and functioning of the Senate. Three points of particular importance were stressed. First, the Senate was meant to be complementary to the House of Commons, not a legislative rival. Second, establishing the Senate as a chamber of "sober second thought" meant that its primary role is to review and propose improvements to legislation. Finally, the Senate was meant to be independent of the whims of public opinion and, also, free from control of governments and the short-term political considerations of political parties. Given that these points help to explain, at least in part, the original motivation for having an appointed rather than elected Senate, as well as the original lifetime appointment of Senators, the conference conversation was not dominated, as many expected, by talk of rebalancing provincial representation and approaches to electing Senators. Indeed, much of the discussion of the post-reference landscape and the space for Senate reform paid considerable attention to the possibility of constructive non-constitutional reforms designed to allow the Upper House to fulfill its original purpose as a complementary, but independent chamber of sober second thought. 
Several of the speakers focused on the importance of achieving clarity on two key matters. First, what do we want the Senate to do? And, second, how, in practical terms, should we operationalize these concepts of "complementary," "independent," and "sober second thought"? While there was no agreement on exactly how to answer these questions, most presenters accepted their primacy and, as a consequence, panelists seemed comfortable with traditional notions of maintaining the Senate's independence from both the government of the day and the House of Commons. For example, Simon Potter of McCarthy Tétrault spoke for many at the conference when he stressed the importance of protecting Senators from being "whipped" by government and party leaders in the House of Commons. There was even a fair willingness to embrace the idea that the Senate should remain free from the whims of public opinion, and this meant there was a good level of comfort in many quarters with maintaining an appointed Senate as the Upper House in Canada's bicameral Parliament.

Many speakers at the conference were emphatic that, rather than making Senate reform impossible, the Supreme Court merely clarified the rules that apply to different reforms. Moreover, despite expressions of skepticism from participants such as Liberal MP Stéphane Dion, participants such as the Liberal leader within the Senate, James Cowan, stressed that even reform of the constitutional variety would be possible if the federal government committed to engaging the provinces in constructive dialogue. Even still, speakers were inclined to turn away from agendas that involved constitutional reform. Apparently accepting the prevailing political assessment that far-reaching Senate reform is politically impractical, if not constitutionally impossible, most of the proposals for reform put to the conference were relatively modest. In fact, much of the conference's attention was on reforms that could be implemented unilaterally by the federal government or, in many cases, by the Senate itself. One exception to this was the proposal by Professor Bruce Hicks, Adjunct Professor in the Glendon School of Public and International Affairs at York University, for readjusting the number of seats in the Senate to be more regionally representative. Drawing on his earlier work, Professor Hicks proposed giving each province six senators and then providing larger provinces with additional regions that would increase their Senate representation. ${ }^{9}$

\section{The Reform Agenda}

As they have been since the original confederation debates, the three core issues regarding Senate reform addressed at the conference were the number and distribution of seats, the Senatorial selection process, and the role and powers of the Upper House, including its relationship to the House of Commons. Given the Supreme Court's ruling that fundamental alterations to the selection process - such as consultative elections - would be subject to the general amending formula, the conference heard more modest calls for different forms of independent input into the appointment process. This included Stéphane Dion's support for the Trudeau Liberals' proposal for an Act of Parliament establishing an advisory panel that would recommend a short list of potential appointees to the Prime Minister for consideration. The consensus amongst the presenters was that the unilateral establishment of some form of independent input into the appointment process would be allowable, although Professor Hugo Cyr, who was originally scheduled to be in attendance, has posited that this form of advisory process would also require the use of the general amending formula. ${ }^{10}$ While Bruce Hicks expanded this discussion by mentioning the possibility of provincial input or power of appointment for Senators representing them, and an attendee suggested from the floor the idea of a House of the Provinces - in the German Bundesrat model - the discussion of selection and appointment was quite limited.

There was, then, as mentioned earlier, a surprising amount of comfort with federal appointment as the method of selection for Senators. There were, to be sure, calls for the appointment process to be better informed by voices from outside of the Prime Minister's circle of partisan political advisors. But, only Conservative MP James Rajotte defined the issue as a democratic 
one that needed to eventually be addressed by establishing a process for Senate elections. In fact, it seemed that many of the presenters at the conference saw the independent appointment of Senators as a way to ensure their freedom from the controlling influence of partisanship, which is essential to ensuring the Upper House's ability to provide independent review of legislation. Concern was also raised with regard to whether an elected Senate could remain complementary to the House of Commons, rather than evolve into a rival elected Upper Chamber.

New Democratic Party Member of Parliament Craig Scott, who, like his party, favours the eventual abolition of the Senate, claimed the NDP has long called for initiatives to remove partisanship from the Senate. Professor Adam Dodek, of the Faculty of Law at the University of Ottawa, went as far as to suggest the formal prohibition of partisanship - in the form of partisan activities - from the Senate. ${ }^{11}$ But the conference rapporteur, Roger Gibbins, Professor Emeritus in the Department of Political Science at the University of Calgary, suggested it would run against the very human nature of people interested in serving in the Senate to prohibit partisanship. Thus, conference participants gravitated toward distinguishing between understanding the problem as one of partisanship versus understanding it as a problem of party discipline. David Smith, who is currently a Distinguished Visiting Professor at Ryerson University, suggested that the goal should be to remove individuals from the pressures and constraints of party discipline - from what Simon Potter and others called being "whipped" by party leaders in the House of Commons. There was considerable consensus that this is a major problem with the current Senate, and it is a problem that seems to be increasingly pronounced over time. As such, the call for Senators to be independent from the government that appoints them and from the House of Commons party system was nearly unanimous. There was, moreover, a proposal by Professor Andrew Heard, of the Department of Political Science at Simon Fraser University, to mandate the distribution of Senate appointments between parties in such a manner that there would never be a majority party in the Senate.
The hope, clearly, is that this would institutionalize a culture of cooperation across party lines, thus reducing the impact of partisanship.

When it comes to the role and powers of the Senate and the execution of its responsibilities, there was consensus on the fact that one of the things the Senate can and has done well, is to perform in-depth reviews of proposed legislation. Some conference participants suggested that an important secondary role of the Senate pertains to completing in-depth research into pressing issues of public policy that are not receiving full and detailed attention by the House of Commons. While legislative review falls more clearly within the functions of a complementary legislative body of sober second thought, there is a history of the Senate performing independent policy studies, and panelists seemed confident and comfortable with the notion that the performance of both roles might best be performed by an independent appointed body.

Interestingly, none of the discussions that touched on the role and powers of the Senate, as the Upper House in a bicameral parliament, confronted the abolitionists' claim that the House of Commons could, with a reformed committee system for example, take on what are now core responsibilities of the Senate. Nor, as Roger Gibbins pointed out, was there adequate consideration given to the degree of public acceptance of an unelected Senate performing such roles. Andrew Heard did, however, address the legitimacy of an unelected Senate engaging in legislative review when he suggested that non-constitutional changes to the rule of the Senate in concert with legislation passed through both the Senate and House of Commons could put in place a process-oriented rule structure that limited the Senate to a mere suspensive veto over legislation.

One of the more curious features of this conference was the lack of attention paid to issues of territorial and provincial representation. With the exception of Professor Hicks' proposal for representational reforms, and Professor Smith's warning about remaining cognizant of the institutionalized ties between representation in the House and in the Senate, none of the presenters addressed the issue of readjusting the provin- 
cial and territorial allotments of Senators. One attendee who had worked with Alberta's Select Special Committee in 1985 argued that this was a striking new development. Perhaps the shift away from this focus is a side effect of the difficulties that would face any attempt at constitutional reform of the Senate. But it could also reflect the lessening of the constituency for rebalancing federalism through adjusted Senatorial seat allotments. We are, after all, in an era where some western premiers favour abolition of the Senate and the governing party at the federal level draws much of its support from the four western provinces. As Roger Gibbins suggested, perhaps structural questions like the distribution of seats and the role of the Senate in the federation are, more and more, issues of the past. The once popular Triple-E proposals seem less relevant, and territorial representation won't be as important going forward.

Finally, there were several suggestions, particularly by Professor Linda Trimble of the University of Alberta's Department of Political Science, that would democratize, or maybe more modestly, modernize representation within the Senate. This could be done with constitutional reform by ending the property qualifications, which the Supreme Court said could be done unilaterally by the federal Parliament. It was posited that this would allow for more equitable class representation within the Senate. Professor Trimble also proposed that the Senate could be a more representative body by having a larger cohort of female legislators and, also, increasing representation for groups that are underrepresented in the House of Commons, including women, people of colour, new Canadians, Canadians with disabilities, and Aboriginals. Perhaps expanding the representational goals associated with Senatorial appointments would produce a Senate that is less partisan, while providing novel and important voices to the legislative process that, in the past, have not been adequately heard.

\section{Rethinking Democratization}

Unlike in the 1980s and early 1990s, the issue of democratizing the Senate was not framed exclusively in terms of commitments to electoral democracy. Professor Lori Turnbull of Dalhousie University's Department of Political Science encouraged attendees to consider expanded notions of democracy that could potentially legitimize thoughtful, depoliticized, and representative appointment processes. Additionally, Professor Dodek argued that tackling democratization entails looking beyond the Senate's conventionally-defined democratic deficit, to consider its legitimacy deficit and integrity deficit.

What was said about addressing these so-called deficits? Well, in addition to James Rajotte's more traditional call for Senate elections and the proposals for a more independent appointment process that were discussed above, presenters such as Turnbull and Trimble argued that making the Senate a place where a greater diversity of voices would influence the legislative process would make an important contribution to tackling the democratic deficit. Attendees were reminded that Senators are not the only non-elected participants in policymaking. Currently, public servants and political staff play significant roles in the policy process, as do non-state advocacy groups, policy experts, and others. The key to ensuring that the process remains democratic is, first, ensuring representational balance and diversity in the voices that influence policy-making and, in the end, ensuring that final decision-making authority in the legislative processes rests with elected members of the House of Commons. Indeed, this sort of thinking underpins Andrew Heard's rationale for restricting the Senate to a suspensive veto.

The legitimacy deficit, participants argued, can be addressed through unilateral federal initiatives, including self-reform initiated by Senators themselves. The Senate's legitimacy would be enhanced by adoption of a reformed appointment process that focused on ensuring that highly qualified and more diverse voices are appointed, rather than continuing the tradition of partisan patronage appointments that reward political cronies and stack the Senate in support of the governing party. Addressing the legitimacy deficit will also require increased transparency by the Senate. To this end, Professor Dodek called for rules that would require Senators to treat 
their role as a full-time job. By restricting Senators' ability to earn additional income beyond their Senate salary of approximately $\$ 136,000$ - which is nearly double the average income of a Canadian family - Dodek argued Senators would avoid conflicts of material interest and find it easier to focus more of their attention on their role as Senators. There were also calls for greater transparency with regard to the posting of expenses and initiatives such as the opening up of Senate debates to the public through televised proceedings.

Proposals to address the final deficit, the integrity deficit, also placed a certain faith in modest self-reform. In addition to taking action on openness and transparency, there were calls for a new Code of Conduct for Senators. Echoing themes discussed above, it was suggested this code should address Senators' relationship to party politics, how they would interact with each other and execute their duties as Senators, as well as other matters of ethical integrity normally covered by such codes. It was added that depoliticized appointments of eminent persons representing Canada's diversity would, in itself, do a lot to restore integrity to the Senate.

\section{Is this enough?}

The conference rapporteur, Roger Gibbons, asked if the sort of agenda outlined at the conference would be enough to shift public opinion and, in doing so, deal effectively with the democratic, legitimacy, and integrity issues that the Senate faces. Did we hear enough of the bold vision that was at the heart of this conference's theme? There is no doubt that this agenda of modest and internal reforms are positive contributions to the discourse around Senate reform. Implementing them would go some distance in addressing these issues while also changing, for the better, the Senate as an institution. That being said, observers who believed the conference fell short in providing truly bold visions may not be wrong. For many, a cautious focus on the achievable seemed to be the order of the day.

The most explicit signs of a desire for bold visions and fundamental change came from two of the Members of Parliament who spoke on the political panel. Echoing the proposals of Alberta's 1985 Select Special Committee, the Canada West Foundation, and the Reform Party, EdmontonLeduc's Conservative Member of Parliament, James Rajotte, spoke in favour of moving toward wholesale reform based on a commitment to a Triple-E Senate. He was clear that, for him, modest reforms - even the reforms proposed by the Harper government's Senate Reform Act - are nothing more than a second-best option. Rajotte was sensitive to the political and constitutional challenges to reform that were clarified by the Reference re Senate Reform, and he admitted national and provincial politics had changed over the past three decades. But, he remained convinced that a bold reform plan, in the vein of the Triple-E proposals, remained essential to the future legitimacy of the Senate.

New Democratic Party Member of Parliament Craig Scott, contributed to the discussion of useful modest reforms, particularly those pertaining to ending partisanship in the Senate, but he views those as temporary initiatives. In the longer term, he remains committed to the abolition of the Upper House. Unfortunately, given the widespread agreement at the conference on the importance of an improved legislative process with effective sober second thought, abolition received very little attention as a legitimate option. For Scott, the challenge is locating the debate about Senate reform in a broader debate about parliamentary reform; this is essential, as it allows consideration of important reforms to the House of Commons that would make abolition an option worthy of consideration by scholars such as those who participated in this conference.

One additional bold proposal came in the form of Professor Linda Trimble's suggestion that what might, in the end, be needed is a national citizens' panel on the future of the Canadian Senate, along the lines of the process used by British Columbia's citizens' assembly on electoral reform. This process would allow a representative group of Canadians to come together, learn from experts in the fields of law and political science, and choose a set of reforms that would be 
palatable to Canadians from a range of different regions and standpoints. Of course, such a process would not negate the need for constitutional reform, but it might legitimize proposals and increase the pressure on provincial premiers and their legislatures to support recommendations that emerge from the process.

\section{Conclusion}

In the end, the Time for Boldness on Senate Reform conference may not have laid out an agenda for the sort of bold constitutional Senate reform that organizers had hoped. Given the Supreme Court ruling in Reference re Senate Reform and the lack of political will for federalprovincial constitutional negotiations at the present moment, reform requiring constitutional amendment may be a bridge too far. The conference did, however, reveal just how much could be accomplished without amending the constitution if the federal government was willing to act unilaterally on select issues and the Senate was prepared to pursue self-reform. In fact, some of the proposals for modest reforms and self-reform were quite innovative and could have consequences deep and lasting enough to be considered, in our opinion, "bold." Many of the scholars participating in the conference have contributed to these debates in the past, both in their academic work and in opinions published in policy papers, given as testimony, or in the form of opinion pieces in the news media. Some of them have also contributed to this special issue of Constitutional Forum. Hopefully, the conference and the publication of these papers will contribute to carrying the discussion of Senate reform forward.

\section{Notes}

* Michael Burton is a doctoral student in Political Science at the University of Alberta. Steve Patten is an Associate Professor of Political Science at the University of Alberta and a member of the Advisory Board for the Centre for Constitutional Studies.
1 Alberta Select Special Committee On Upper House Reform, Strengthening Canada: Reform of Canada's Senate, (Edmonton: The Committee 1985). For a brief review of the Report, see: Louis Massicotte, "Parliamentary Book Shelf: Review of 'Strengthening Canada: Reform of Canada's Senate by the Alberta Select Special Committee on Upper House Reform"' (1985) 8:2 Canadian Parliamentary Rev 30.

2 Peter McCormick, Ernest C. Manning \& Gordon Gibson, Regional Representation: The Canadian Partnership: A Task Force Report (Calgary: Canada West Foundation, 1981).

3 Michel Bédard, "Bill C-43: Senate Appointment Consultations Act," Legislative Summary, (2007) Library of Parliament at 1. For background on Bill S-4, see: Sebastian Spano, "Bill S-4: An Act to Amend the Constitution Act, 1867 (Senate Tenure)," Legislative Summary, (2006) Library of Parliament.

4 Bill C-7, An Act Representing the Selection of Senators and Amending the Constitution Act, 1867 in Respect of Senate Term Limits, 1st Sess, 41st Parl, 2011(first reading 21 June 2011).

5 Sebastian Spano, "Bill C-7: An Act respecting the selection of senators and amending the Constitution Act, 1867 in respect of Senate term limits" Legislative Summary, (2011) Library of Parliament at 1.

6 See: Peter J. Carver, "Whose Senate is it anyway?" (2013) 22:2 Const Forum Const 1.

7 Reference re Senate Reform, 2014 SCC 32, [2014] 1 SCR 704.

8 Centre for Constitutional Studies' YouTube channel: <https://www.youtube.com/channel/ UCh4MQysaJQ9x1Hui_qEqiGQ>.

9 Bruce Hicks, "Can a Middle Ground be Found on Senate Numbers?" (2007) 16:1 Const Forum Const 21 at 28-29.

10 Hugo Cyr, "Justin Trudeau's Senate reform plan has no teeth." Toronto Star (11 May 2014), online: <http://www.thestar.com/opinion/ commentary/2014/05/11/justin_trudeaus_ senate_reform_plan_has_no_teeth.html $>$.

11 Also See: Adam Dodek, "Reforming the Senate after the Reference: Mend It, Don't End It" online: (2014) 4:1Constitution.ca <http://constitution.ca/ reforming-the-senate-after-the-reference-mendit-dont-end-it-by-adam-dodek/>. 
Volume 24, Number 2, 2015 